\title{
The Philosophy of Existentialism in the Magus - the Motifs of Freedom and Suicide
}

\author{
Ljiljana Pticina \\ Faculty of Philosophy, University of Novi Sad
}

\section{Abstract}

John Fowles' literary opus is largely based on the philosophy of existentialism, with the motifs of freedom and suicide serving as its focal points, both closely related to freedom of choice and seen as crucial to the existentialist movement, as well as the author himself. This paper analyses Fowles' novel The Magus through the prism of existentialism, which means that the basic existentialist concepts are identified and located within its text, as well as the influences of the key figures of this movement. The motifs of freedom and freedom of choice in context are interpreted and linked to the theories of Freud and Jung while special emphasis is placed on the role of the anima, that is, the female principle inside the male subconsciousness. This is precisely why a separate section of this paper is dedicated to female protagonists and their role in the novel. In his works, Fowles puts an emphasis on the freedom of the individual, which is portrayed through the freedom of the mind, ideas, choice and spirit. It is cruel, always demanding action as well as acceptance and adaptation. By remodelling our own character, we also remodel the future generations and our visions of the world. The protagonist in this novel is chosen to remodel his own character, to turn from a collector into a creator, to stop depriving people of the content and to bring about a positive creative act instead. Human border acts such as suicide also belong to this field of interest. There are three cases of suicide in The Magus and this paper analyses their role as a symbol of the protagonist's metamorphosis upon threading onto the mythical ground.

Keywords: Philosophy of Existentialism, Magus, Motifs of Freedom, Suicide.

\section{Introduction}

Nicholas with the broken pieces of his past, present and future

in his hands constitutes John Fowles's

living icon of the existentialist(Onega, 1986: 106)

The existentialist philosophy is what John Fowles remains faithful to until his death. This also makes him an atheist, since the modern philosophy shifts the focus of doing and thinking from God to man, with Fowles finding himself in a Godless world, where a man "can be interpreted according to his forsakenness or his independence", as Hanna Arent sees it. (Arent, 2013:13). In one of his interviews, Fowles claimed that, for him, Sartre's way of thinking was the most challenging one. Still, one of his definitions fits The Magus rather nicely, since it says that "the existentialist movement defines the man on the basis of his doing" (Cohen-Solal, 2007: 365), that "there is hope solely in his doing, and that the only thing that makes it possible for a man to live is the very act of doing" (Cohen-Solal, 2007:365). According to Fowles, however, the biggest influence for him were the conversations about the Existentialists and authenticity, ones he led during the time spent at the university just like Nicholas Urfe, the protagonist of the novel.

"It corresponded to feelings inside myself that I think would have emerged anyway, indeed had already emerged, if confusedly, but were certainly quickened by the existentialist writers"(Baker,1989).

However, Marxism and Existentialism have appeared recently, as well as a strong criticism of the Catholic Christians. The Existentialists can be divided into two main groups: the Christian one and the Atheist one. According to their views, though, God's presence does not significantly affect the changes in one man's life. "In the new, Godless world, the role of the Lord of Existence, of being, is, so to say, imposed on the man". A certain kind of freedom is forced on the man-Sartre himself says that a man is condemned to be free" (Cohen-Solal, 2007:365). The man did not create himself, and still, he was given the freedom of choice and the absolute necessity of taking responsibility for his actions and choices. Sartre believes that not making a choice is also an act of choosing. Every action, or the lack of it, has certain consequences, reactions, and it 
affects us, as well as those around us. This is precisely why we have to think of the other ones too, even while being free, which, according to the existentialist atheists, serves as the basis of morality and a substitute for God's Ten Commandments.

"A man free in his very essence is helplessly handed over to the natural course of things, one strange to him, to his contrary fate, which destroys his freedom". Apart from freedom, the Existentialists pay close attention to the borderline acts of life, such as death, guilt, fate and coincidence "because in all these experiences, the reality is seen as imminent, one which cannot be decomposed by the act of thinking" (Arent 2013: 11). What drives the plot ahead and is seen as inseparable from the existential philosophy- and from Fowles as an author-is the existence of choice: "The act of choosing is possible, on one hand, but the act of not choosing is impossible, on the other. I can always choose, but I must also be aware of the fact that, by not choosing, I also choose". (Jean-Paul Sartre, 1981: 278). One of Fowles's short stories, The Wall, depicts what is regarded as Sartre's philosophy in a matter of a few pages only. Three men on a death row are waiting for the execution of their sentence. Finding themselves in a fait accompli kind of a situation, they have the right to choose the way of facing the firing squad and the way they die-with dignity, concealing their fear and the omnipresent human dilemma of what comes after, or without it, by completely giving themselves over to the ridicule of the enemy.

\section{The existentialist understanding of freedom and freedom as a motif in The Magus}

The world wants us caged, in one place,

behind bars; it is very important we stay free. (Fowles)

Freedom is the most commonly used and misused word. No matter how often uttered by the contemporary man, it is rarely found as a thing learnt from experience. Freedom itself, as well as the level of its presence or absence can be regarded differently. Slavery is not depicted by chained arms and legs only-it can be found in the spiritual world as well. "The freedom of spirit is a holy symbol, its meaning cannot be related to the temporary or transit forms of this or that period. But, freedom within the social, political, even cultural sphere has stopped inspiring, everyone is sick of it and no one believes in it anymore. We live in the era of reduction of freedom. Freedom is distorted. It has become a conservative principle and it concelas a man's slavery rather often" (Berdyaev, 2006: 27-28).

In his novels, Fowles accentuates the freedom of the individual in accordance with the existentialist philosophy. This freedom is not portrayed by the physical capabilities or incapabilities, but by the freedom of the mind, ideas, choice and spirit Berdyaev talks about. It is freedom "sui generis, limited, conditioned, confined" (Abanjano, 1967:55) by the freedom of the others which needs to be qualified as well, but also by the the choices and possibilities. That is exactly what the protagonist's quest is based on in The Magus. Nicholas Urfe believes that everything is in Conchis' power, as is the case with Prospero in The Tempest, without realising that the game adapts to his choices, decisions and acts. Because "the man is thrown into the world and responsible for everything he does." (Sartre, 1981: 268). That is a life lesson that Fowles wants to teach both Nicholas and the reader.

"It was always meant to set questions rather than give answers - like a Rorschach test... no "right reaction", no one correct solution to all the clues. (...) Conchis is not meant to represent God, but the human concept "God"- an important distinction" (Vipond, 1999: 27). Николас представља човека уопште, што је наговештено и његовим презименом: "Urfe stands for Earth - Everyman" (Vipond, 1999: 27).

Freedom does not mean just freedom of choice, but the choice itself as well. Nicholas has accepted the game by his own free will/choice and wants to stay in it, which is a fact confirmed by his own thinking: "I felt a sudden rush of fear because of last night. It is all over. They have all disappeared, forever" (Fowles, 1994: 270). What Nicholas needs to learn and realise is that freedom is "bound to bring about a positive creative act". Still, we are not limited by other individuals only. Fowles claims that freedom is cruel (Fowles: 1994: 443), it demands responsibility, action, but also acceptance, adaptation and coming to terms with the situation. "Learn to smile, Nicholas" (Fowles, 1994: 443). That reaction, that smile "is not so much an attitude one can have towards life, but the very cruel nature of life, the cruelty whose avoidance we cannot even opt for since it is human existence (Fowles, 1994: 443)“. A man is always given the freedom of choice, and every chosen path has certain consequences. It can be said, though, that freedom always exists in that spiritual, mental segment. If nothing else, it is more present than in the material world. "Utter freedom exists for the spiritual life only, for the human mind and consciousness, the intimate life of the individual" (Berdyaev, 2006: 33). The author offers an explanation for this by claiming that freedom is "inseparable from the being itself, it is rooted in nothing, in the abyss, in the non-being. (Berdyaev, 
1991: 82). Another Existentialist, Nicholas Abinjano claims that human freedom is limited by the choices, that is, the conditions created separately from the man himself. That human freedom is what determines the good and the bad.

"We can always say no to evil, no matter how limited our choice is. And we can always say yes to the good. Both good and bad will to some extent depend on that yes or no of ours. The freedom limited in that way, determined by the conditions and obstacles of every kind is the type of freedom typical for the human being" (Abinjano, 1967: 56).

Consequently, it is all up to Nicholas-he chooses to leave Alison, to go to Greece, to go to Burano even though he has been warned, to continue playing, because the continuity is solely in his hands. It becomes clear how dependent on Nicholas' choice the game is when he comes upon a number of changes in the scenario in the hidden chambers of the actors, Julie/June and the other ones as well. Fowles send the message that "freedom means choice" (Abinjano, 1967: 57). The most striking situation in which Nicholas has a choice is his trial, when he is given the option of punishing Lily/ Julie by whipping her, in order to relaese his own fury for all the deceptions, lies, games and fears. Nicholas is, at this point, closer to the goal he was led to by the teacher, Conchis, and it seems that he starts to understand the role he has been given. "The better you understand freedom, the less you own it." (Fowles, 1994: 432).

If we realise that we are equally blessed and confined by it (freedom) or maybe even punished, it will be clear to us that there is only one way a man can reach the absolute truth, the truth Nicholas is looking for-it is simple, easily reached, it is at everyone's grasp, it consists of the direct knowledge of oneself" (Fowles, 1994: 246).

"And my freedom was in not hitting, no matter what price I paid, even if the remaining eighty parts had to die within me, no matter what the gazing eyes thought of me, even if it seemed that I forgave them, as they phrophesied I would, that I was indoctrinated, that I was their fool" (Fowles, 1994: 246). Even though Nicholas thinks that the game is over after this, it does not finish, however. One of the more significant choices-later on-will be the offered suicide, which Nicholas will consciously decline because he does not want the real death, but the symbolic one. By the end of the novel, by his next encounter with Alison he does not understand that the choice does not lie in the game only and that the game depicts reality, real life, that every next step depends on us, our deeds and our respect towards someone else's freedom. It is what Choncis also tries to tell him when they talk about Lily's problem with schisophrenia. At that point Nicholas still does not realise that Lily's recovery is a symbolical representation of his own recovery. "It is with this situation that I wan to make this poor child see that her problem lies in the fact that she lives in artificial circumstances which we are here creating by our jonit effort. Her first, healthy step towards the normal will be the day she stops and says. This is not a real world. These are not real relationships" (Fowles, 1994: 237).

That poor child, who needs to realise that the relationships prepared for him are not real and that things do not take that course in real life, is Nicholas. The final goal is to see what lies behind the appealing portrayal of a naive and innocent Victorian girl, and that it is the very thing he needs to embrace and accept without wishing to change it and without yearning for the unknown. Conchis says that the chances for the "poor child" to recover are slight, but that they exist. He still talks about Nicholas. Nicholas is the chosen one, one of many, but he himself cannot affect it in any way. "You are chosen by coincidence. You cannot choose yourself" (Fowles, 1994: 75). He is chosen because he encompases the traits of two types of people that Fowles sees in this world: the Collectors and the Creators.

"[...] in the case of d'Urfé rather than classes of people, the "collector" and the "creator" represent deep human traits to be met with simultaneously in the same person. This point is crucial, for it explains why Miranda is unable to "teach" Clegg while Conchis succeeds in his teaching of d'Urfé" (Onega, 1986: 75).

Nicholas has the possibility to decide which path he wants to take-whether he will become and remain a complete collector, or turn towards the other type of people and take complete responsibility for his deeds. The first step is self-consciousness, followed by the taking of complete responsibility for the existence of what we are (Sartre, 1981: 263). Miranda, the heroine of the Collectors, fails to reach her physical freedom due to her inability to communicate with Clegg. She is, in some way, given the role of the teacher, the magus, but she fails to understand the way the consciousness works, as well as the world her student lives in, she does not realise that he lives in a fantasy world of unrealistic relationships and that her role is to turn his attention towards those relationships, to bring him to the finishing line. It all ends with her freedom of speech, art and physical death. Understanding, realisation, and catharsis do not provide the protagonist with the solution, the clearing of the mystery and the ending of the quest. Aleksandra Jovanovic talks about epiphany as something that does not cause utter satisfaction which actually happens to Nicholas. It "only opens the possibility for new epiphanies. The function of 
epiphany is to point the protagonist's, and the reader's aspiration towards the discovery of the mysteries" (Jovanovic, 2007:35). The trial scene is the epitome of waiting and patience. Because "every little thing on the isle of Burano is a scene for Nicholas, an Ariadne's thread that leads to freedom and freedom is the return to the inner existence, subjectivity, character, freedom and spirit" (Berdyaev, 1991: 99). "When the actors retreat after the trial, Nicholas has to learn to love without inflicting pain and to acquire the archetypal energy he has discovered in order to be ready for the key events of his transformation, an encounter with the Goddess-his real anima Alison" (Jovanović, 2007: 174).

Fowles creates characters-collectors as a response to the existence of the people who break the freedom. "The collector is thus the most unimaginative being of all because he fails to grasp the fullness and the unforseeability of life" (Jovanović, 2007: 70-71). One of such characters in The Magus is Alphonse de Deukan, to whom hoarding was a way of life. His collecting was made up of objects. Nicholas Urfe, however, has a collecting consciousness as well because Fowles regards those who collect people as collectors, too. Such is the case with Clegg from The Collector, where this act is brought to the point of nakedness. Nicholas "collects" girlfriends by not involving himself in romantic relationships, so the girls are just a kind of a succession to him. The are all, either physically or metaphorically, collecting people. And by classifying them, they actually empty them and deprive them of their content. Having left Burano, Nicholas goes back to his collecting habits by sticking little Joe to himself while waiting for Alison and paying for her company, to lessen his loneliness and make the waiting bearable, neglecting the possibility that Joe might really fall in love with him, which actually happens. By doing this, he still inflicts pain, classifies, makes her worthless and deprives her of the content. The Conchis guides Nicholas through the God Game by narrating different stories to him. They are all related to the upcoming events and aim to serve as some kind of a mirror to Nicholas. The most strikingly depicted story in terms of freedom is one dating back to the period of the Second World War, especially for Nicholas, for whom the scene was arranged face to face. A compelling scene of the strength of a totalitarian, opressive regime is shown, as opposed to the will and the freedom of an individual. The existentialist Berdyaev points out the importance of the role of character, because the being is abstract in itself. "Character is more important than being (...) Getting to know the character and freedom is connected to personal understanding, will and activity" (Berdyaev, 1991: 82-83).

On the opposite side of character is the regime, the system represented by Wimel, a ruthless, merciless person with no sense of guilt. He is given the role of God, he is the one who offers a choice-either using violence on another human being, to dirty his hands with another one's blood, inflicting pain and perhaps liberating other eighty lives or staying consistent and sacrifising his own and someone else's life. "Where there is violence there is no freedom because these two principles cancel each other out. One could think (we would not neglect that possibility either) that the one using violence is free to choose his own behaviour, but (...) by opting for the forms of violent behaviour, the man loses his humanity, his own self and becomes the prisoner of his beastlike nature" (Varnica, 2012: 5).

The deprivation of all forms of individuality was typical for the concentration camps and the national-socialist ideology which becomes the central point of the occupation of the Greeks on the island of Farkos, and Conchis's role as a mayor. This was also the rule applied to the German soldiers as well-the deprivation of charachter equals the deprivation of freedom and spirit, and that empty content is further used as one sees fit. This is what Fowles illustrates in the scene where Wimel, as an executor, does not carry his tasks out by using his hands, but his position. "Maybe that is the reason he could impose hismelf so strongly as a black deity. Because there was something more than human in his spells. The real evil and true monstruosity of the situation thus lies in other Germans, those lieutenants, corporals and soldiers less crazy than he himslef was, who stood there silently and regarded this exchange" (Fowles, 1994: 362). Nipping individuality in the bud means "destroying spontaneity, the man's power to start something new based on his own powers" (1998: 462).

"Ghastly, human-like marionettes start to appear instead, all of them behaving as the dog from Pavlov's experiment, uttely predictable, that is, even while heading towards death, doing nothing else but reacting. That is what the real victory of the system over man looks like" (Arent, 1998: 463). The regime is the only meaningful thing there is. The trapped partisan does not behave the way the system would like him to. Even after a horrendous torture, he insists on one word only-freedom. "In my world, life had no price. So worthy was it that it was regarded as literaly pricless. In his world, however, there was only one thing that had such a priceless quality: eleutheria. Freedom. (...) I saw a person in the square who had the freedom to choose and to publish it. The defense of that freedom was more important than common sense, self-preservation, yes, more important than my own life and the lives of eighty hostages" (Arent, 1998: 363).

The situation that fate puts us in always offerx the possibility of choice, and it is up to us to make the final decision. It is our deeds/actions that reveal our authenticity. "The man is responsible in front of himself and the others, but as the free ones 
only, those who have freely chosen their act and do not regret it. Freedom is complete, limitless and absolute, since it depends on the self (authenticite), one's own choice (choix) and draft (projet, Entwurf) of the human act" (Pejović, 1979: 117). In this story, Conchis opposes the whole regime, ideology, enemy and teaches Nicholas the importance of our authenticity as human beings. "The human race is not important. We must not betray ourselves (Fowles, 1994: 113). He teaches him something else, too-that the lack of bravery to get to know oneself and respect ourselves causes the loss of freedom, both for us and the others. "The tragedy is not that one man is brave enough to be evil, but that millions of people are not brave enough to be good" (Fowles, 1994: 113).

It is at this point that Sartre's influence can be seen, since he claims that "by choosing myself, I choose humanity", reckoning that by remodelling the reflection of our own character we remodel the future generations and our own visions of the world. The man needs to discover, see and respect the others, and later on, to discover them as "the condition of his existence" (Sartre, 1981: 276).

\section{Female protagonists and the motif of freedom}

John Fowles is regarded as someone who favours female characters in his novels. There are few of them in The MagusAlison, Lily/Julie, Rose/June and Mrs De Seitas. Their role, when compared to the content, is a more passive one.

Beneath the aloofness which seems to signal a poised self-sufficiency, the Fowlesian heroine is a passive figure, invariably compromised and controlled by the strategies of the text that contains her" (Cooper, 1991: 11).

In one of her conversations with Nicholas, Lily points this situation out. "We are, if you like it, a few steps further than you in the labyrinth. Which does not mean that we are any nearer to the centre than you" (Fowles, 1994: 197). On certain occasions she resembles Ariel from The Tempest more than Miranda. Sometimes, she is only there to set or prepare the scene for the further development of events. Alison, Nicholas' anime, has a similar role. She appears in the first part of the novel only, as one of the striking characters, occasionally croppinng up in its middle and end parts, but with a significant role for the further development of the plot. The plot is vowen aroun her, but she does not take part in it directly.

At one particular moment durung his quest, it seems to Nicholas that Lily de Seitas is the key to the riddle. A mysterious and graceful mother, one who knows and teaches. She was originally intended for Conchis' role, but Fowles abandoned the idea. Lily de Seitas remains a passive contestant of the metatheatre and Nicholas' journey through the existentialist quest, especially after being submitted through content to Conchis as his mistress. Despite that, women are portrayed as strong charachters, able to control themselves, perserve the knowledge and transfer it. The male is on the path of selfawareness and the female protagonists are the ones helping him "You are still becoming. You still do not exist" (Fowles, 1994: 94).

Fowles himself confirms that he respects the female principle and that women are bigger heroes of our time than men are:

"I have great sympathy for the general feminine principle in life. I find very little "heroic" about most men, and think that quality is far more likely to appear among woman in ordinary, non-literary life. [...] In terms of history men have failed; it is time we tried Eve" (Baker, 1989).

Pamela Cooper claims that freedom and independence are not always as ambiguous as they might seem. "This is particularly true when the quester after liberation and self-determined identity is a woman" (Cooper, 1991:10). In The Collector, for example, Miranda tries to help Clegg/ Cannibal to dispose of the inhuman part of his nature, regarding herself as superior and free in relation to him. Her physical freedom is undoubtedly questioned, while in her own world, one Clegg took her away from, she depends on another male, who teaches her and shapes her emotionally.

Jung believes that it would, first of all, be necessary to accept the inner realities in order to come to terms with the problem of the anima for real. The anima serves as a kind of compensation for the male consciousness, while the Animus is the compensating figure for the male character in women. "If the outside world is just a phantasm for me, how, then, can I put serious effort in creating a complicated system of relationships and adaptations" (Jung, 1971: 271). Conchis was given the role of the teacher, the magus who will help the protagonist-the seeker to get to know his „inner realities", and one of the roles of the female protagonists is to carry out the initiation, the separation from the previous life, from the mother and childhood, that is, a rebirth and settting up a new view of the world, since Julie is Nicholas' false anima. Julie/ June/ Liliy de Seitas/ Alison- All of them are authentic and self-aware, this not being the case with Nicholas. According to Sartre, the man becomes a slave to the other, if, in the depth of his being he depends on another one's freedom (1981). 
"When all the public things slide into the abyss of slavery, the only option available to the man is to try to compensate his complete lack of freedom in all walks of life by the freedom of the most intimate and indivudual sphere, of utter privacy: by limitlesly owning other bodies, he is "totalised", as if he is delving into the very origin of the being, as if he manages everything" (Pejović,... 119). The body and the consciousness are one thing, but the problem arises when there is insincerity. "It is a delusion, self-deception, self-sacrifice, in one word, non-dinstictiveness" (Pejović, 1979: 120).

\section{Suicide within the existentialist philosophy and as a motif in The Magus}

As it has been explained earlier on, the existentialists deal with the border cases of philosophy such as death, guilt, fate, coincidence and suicde.

"For the existentialists, suicide was not a choice shaped mainly by moral considerations but by concerns about the individual as the sole source of meaning in a meaningless universe"("Suicide", 2017).

Camus gives a fair amount of space to this phenomenon in his work The Myth of Sisyphus.

"Sisyphus heroically does not try to escape his absurd task, but instead perseveres and in so doing resists the lure of suicide. Suicide, Camus contends, tempts us with the promise of an illusory freedom from the absurdity of our existence, but is in the end an abdication of our responsibility to confront or embrace that absurdity head on"("Suicide", 2017).

Camus claims that the meaning of life is the most important question. (Camus, 1998, 9). Determining whether or not there is any sense in living means answering a profound philosophical question. (Camus, 1998, 9). Camus believes that in the cases of such an inspection, the judgement of the body is as important as the judgement of the mind and that the body retreats in front of the destruction. We get used to living even before we acquire the habit of thinking (Camus, 1998, 12). So, there is a discrepancy between thinking and living, which means that life and reality do not always coincide. For another existentialist, Jaspers, thinking plays an important role, one by which "it has the function of alluring the man into certain experiences, experiences in which only the process of thinking (...) will go through a breakdown. That breakdown brings about a providence which makes the existence aware of the fact that a catastrophy is imminent and that it does not owe itself to itself only, as is the case with freedom. It is important to direct oneself towards communicating with the others.

In The Magus, the act of suicide is described by Nicholas Urfe as the person who has already gone through the story the reader has yet to hear. Nicholas definitely did not think so thorougly at the moment the desire for suicide cropped up, as Nicholas, the narrator and the detoxicated protagonist-the seeker, does. It is exactly what this effort causes, acceentuating the thinking process and communication with other people. Nicholas' inner realities have not come to the surface yet, his perception of life and the world around him is, at that point, still a product of fantasy. The act of attempting suicide is the first step towards the quest for authenticity.

Let's take a look at a somewhat differnt existentialist, more prone to religion, that is, Christianity. Nikolaj Bredyaev believes that committing suicide is not so easy and that we need an enormous amount of determination for that feat "But, in reality, suicide does not reflect the strength of human character, it is executed by an inhuman force that carries out that scary and cumbersome task". He (the man) is obssessed with the darkness that has taken over him, and he has lost freedom" (Berdyaev, 2011, 17). If we neglect his orientation towards God, one can say that Berdyaev has a certain kind of attitude in the moments when a man is trying to commit sucide, one which is similar to the other existentialists'. "To overcome the wish to commit suicide means forgetting oneself, thinking of the others and within the others" (Berdyaev, 2011: 12), that is, a man should learn to step outside himself and his self-obsession and open up towards other people and the world, the principles that have the universal meaning.

Suicide as a motif in The Magus appears on three ocassions. The first time, Nicholas wants to commit suicide on the island. "I belonged to nothingness, neanty, and it seemed to me that the only thing I could create was my own death" (Fowles, 1994: 53). At that moment, Nicholas Urfe unambigously resembles Jaspers as portrayed by Camus.

"In this devastated world where the inability of self-awareness has been proven, where nothingness seems to be the only reality, despair with no shelter, the only attitude, he is trying to find Araidna's thread that leads to divine secrets" (Camus, 1998: 26).

Nicholas thinks that he has found that thread and compares Ariadne to Lily/Julie. "I would not switch places with anyone in this world, now that I have found my Ariadne and held her hand" (Fowles, 1994, 177). The way Susan Onega sees this first 
attempt of suicide is extremely interesting. Nicholas puts himself into the position of self-pity where a sentence "le suis maudit" in the doctor's office, after he has been diagnosed with a sexually transmitted disease, clearly shows it. All these events, and especially his inability to take a reality check, to see the gist of the problem, bring him to the point of thinking about suicide. But he realises that he does not really want to kill himself, that he does not really want to die. It is as if he wants to attract attention, as a mollycoddled child does. "All the time I had this feeling that someone was watching me, that I was acting for someone else's benefit, that this act could only be carried out if it were spontaneously clean and moral (Fowles, 1994: 54). Upon the first reading of the novel, the feeling that Nicholas is being watched by someone creates a completely different atmosphere than the one the reader expweiwnces after the second reading. On the first reading, we identify with the charachter and we really believe that Nicholas is under close inspection of someone's game, and we feel what happens is not justified. But, by delving into the analysis, we can treat Nicholas' giving up on the act of suicide as his sucess of not falling over the brink that is mentioned by Camus- treat it as the start of turning towards the others and not only his own existence.

"I have looked for Mercucio's death, not the real one. I wanted a memorable death, not the real one, caused by the real suicide, the death that wipes everything out" (Fowles, 1994, 53).

After that, both Nicholas and the reader encounter another suicide-Alison's. During the protagonist's quest neither the hero nor the reader know that the news about this suicide is falsified and that it is just another epiphany on this quest. Nicholas recieves another succession of letters which seems identical to the original one, and is used to substantiate the made-up news about the stewardess' suicide, caused by an unhappy love story. This tragedy occurs after Nicholas has spent a few days with Alison in Greece, believing that he has succeeded in deceiving both girls, Alison and Julie, by hiding the real state of affairs from both of them, and most of all, from himself. This self-deception had to be shaken and the protagonist needed another epiphany, although a bit cruel one. Namely, Conchis plays with Nicholas' feelings ruthlessly, but if take a look at things from another angle, Nicholas is the one who is constantly playing with other people's feelings, without thinking about the mental state of those people he leaves behind.

Let's go back to Nicholas' first suicide attempt. Onega interpretes it through Campbell's terminology, claiming that his symbolic suicide can be seen as some kind of self-anhiliation. This is necessary in order for him to step onto the holy ground of the Burano island. Gargoyles used to stand as guards at the door of the temples, but the verses of warning are quoted instead (Onega, 1986: 78- 79). The act of suicide represents a symbol of metamorphosis of the protagonistbecause he threads the part of the territory where the collapse of the mythical is felt. On the second ocasssion, Nicholas does not even try to commit suicide, but he is well aware of the fact that the pistol is left behinnd with that purpose for him. This is also a symbol. He has faced another thershold one should cross, so a new initiation is needed. Still, as it becomes clear up to this point, real death has not been the goal, neither the teacher's nor the student's, neither the first nor the second time, but the quest for the inner truths, authenticity, that is, the distinctiveness, as Pejakovic calls it. The intrveawing of of the philosophical (existentialist) and the mythical motifs pervading the novel is more than obvious.

\section{Conclusion}

John Fowles' literary opus was a subject of many monographies, $\mathrm{PhD}$ theses and essays/articles in scientific magazines. His novels are on the border of modernism and postmodernism. By using experimental method, he disturbs the realistic narrative. One of his main techniques is the unfinished ending, by which the reader questions himself and has the freedom of interpretation, the freedom of looking for his own authenticity by going through the labyrinths and the mythological paths of the novel's protagonists. The ideas that Fowles does not abandon are freedom, seleflesness, and the existentialist philosophy. They are the goal of his protagonists' quest, who are seen as potential mythical seekers. As an existentialist, he has mostly succumbed to Sartre's ideas, and these are indeed traceable in the novel.

That is precisely the reason why this paper deals with the motifs of freedom and suicide as borderline situations people find themselves in, which is of utmost importance for the existentialist philosophers. The open-endeness of the novel is another thing that needs to be pointed out, not only in terms of its ending, but also the interpretation itself Fowles does not want to be categorised, and every interpretation is the correct one. For him, mistery is the driving force while the final answers are regarded as a kind of prison and have a destructive power. 


\section{References}

[1] Fauls, Dž. (1994).Čarobnjak. Novi Sad: Matica srpska.

[2] Abanjano, N. (1967).Mogućnost i sloboda,Beograd:Nolit.

[3] Arent, H. (1998).Izvori totalitarizma. Beograd:Feministička izdavačka kuća 94.

[4] Arent, H. (2013).Šta je filozofija egzistencije?Beograd:Dosije studio.

[5] Baker, J.R. (1989). John Fowles, The Art of Fiction, The Paris REVIEW, (Issue 111). Retrieved from https://www.theparisreview.org/interviews/2415/john-fowles-the-art-of-fiction-no-109-john-fowles.

[6] Berđajev, N. A. (2011).O samoubistvu, Beograd: Logos.

[7] Berđajev, N. A. (2006). Sudbina čoveka u savremenom svetu: za razumevanje našeg vremena.Beograd: Logos.

[8] Berđajev,N. A. (1991).o čovekovom ropstvu i slobodi: ogled o presonalističkoj filosofiji.Novi Sad:Književna zajednica.

[9] Cooper, P. (1991). The Fiction of John Fowles.Ottawa:University of Ottawa Press.

[10] Hačion, L. (1996).Poetika postmodernizma.Novi Sad:Svetovi.

[11] Jovanović,A. (2007).Priroda, misterija, mit.Beograd:Izdavačka kuća Plato/ Filološki fakultet.

[12] Jung, K. G. (1984).O psihologiji nesvesnog.Novi Sad:Matica srpska.

[13] Kami, A. (1998).Mit o Sizifu. Zagreb: Matica hrvatska.

[14] Koen-Solal, A. (2007).Sartr: 1905-1980. Novi Sad/Sremski Karlovci: Izdavačka knjižarnica Zorana Stojanovića.

[15] Onega, S. (1986).Form and Meaning in "The Magus", Miscelanea, (no. 7).Zaragoza:University of Zaragoza.

[16] Pejović,D. (1979).Suvremena filozofija Zapada, Zagreb:Naklada Matice hrvatske.

[17] Salami, M. (1992).John Fowles's Fiction and the Poetics of Postmodernism.London/Toronto:Associated University Presses.

[18] Sartr, Ž.P. (1981).Filozofski spisi. Beograd: Nolit.

[19] Suicide. (2017). In E. N. Zalta (Ed.), Stanford Encyclopedia of Philosophy. Retrieved from http://plato.stanford.edu

[20] Tišma, A. (2012).Kapo,Novi Sad:Akademska knjiga.

[21] Vipond, D. L. (1999).Conversations with John Fowles. University Press of Mississippi. 